\title{
Paul D. Leblanc, Deciphering the Proto-Sinaitic Script. Making Sense of the Wadi el-Hol and Serabit el Khadim Early Alphabetic Inscriptions, Ottawa, Subclass Press, 2017, 372 pp., 22\$.
}

https://doi.org/10.46543/ISID.2029.1009

Este canadiense, casado y padre de dos hijos, con un máster en Estudios Religiosos por la Universidad de Ottawa, comenta al comienzo de su obra (en el apartado de agradecimientos), que fue su situación de"desempleado" la que lo llevó a emprender este proyecto, meditado desde largo tiempo. Cuando uno se asoma al índice del libro, la obra promete. Está dividida en cuatro partes principales. En las dos primeras se dedica a una nueva propuesta de lectura y traducción de las principales inscripciones encontradas en los yacimientos arqueológicos que menciona en el título. La tercera parte está constituida por una serie de conclusiones que extrae de los resultados obtenidos en las dos anteriores; y la cuarta contiene un apéndice de naturaleza filológica, las notas a pie de página, las imágenes e ilustraciones, y la bibliografía.

La lectura de las dos primeras partes resulta sugerente, pues el autor plantea una metodología innovadora para enfrentarse a los textos proto-sinaíticos. De hecho, él considera que en las inscripciones coexisten la representación de fonemas alfabéticos semitas y los glifos ideográficos egipcios. Es más, cree que el escrito, redactado en una lengua semita, acoge también elementos camitas. Esto le lleva a ofrecer traducciones muy distintas de las propuestas hasta ahora, con lo cual el interés del lector se despierta.

Pero la tercera parte representa una decepción ante las expectativas creadas, cuando se pone en evidencia que las ideas vertidas en ella han guiado, incluso forzado el proceso de interpretación. Leblanc pone todo su esfuerzo anterior al servicio de una teoría según la cual, las principales tradiciones del Pentateuco, esto es, los elementos fundantes de la fe israelita, no serían más que una relectura semita del patrimonio religioso e histórico de Egipto. Así, bajo el relato de la creación, subyacería el mito del Ogdoad egipcio; el personaje de Noé se inspiraría en $\mathrm{Nu}$, y el arca y el diluvio, en el mito de la barca solar; la tríada tebana habría sido la fuente para modelar las figuras de los patriarcas; y bajo la figura de Moisés y el relato del Éxodo, estarían las figuras de faraones prominentes Amosis I y Kamosis I, claves en la lucha para la expulsión de los hicsos. Este último evento sería para él el acontecimiento histórico sobre el que los Aamu (antepasados de los israelitas) habrían dado forma al relato de la salida de Egipto.

En síntesis, no se puede evitar la impresión de que Leblanc ha empezado la casa por el tejado, pues su labor filológica e interpretativa acaba siendo la coartada para sus hipótesis históricas y antropológicas, lo 
cual termina restándole valor, e impidiendo que puedan tener la solvencia de las de los grandes especialistas: Albrigth, Gardiner, Rainey, Sass, Goldwasser, Wilson-Wright, etc.

Pablo Díez Herrera

Facultad de Teología San Isidoro de Sevilla pablodiezherrera@gmail.com

\section{Gianfranco Ravasi, Adán ¿dónde estás? Preguntas antropológicas contemporáneas (BAC Popular 244), Madrid, Biblioteca de Autores Cristianos, 2020, 69 pp., $9 €$.}

https://doi.org/10.46543/ISID.2029.1010

El autor de este libro es Cardenal Presidente del Pontificio Consejo de la Cultura. Estudioso de la Sagrada Escritura, infatigable y ávido lector, con prodigiosa memoria, Gianfranco Ravasi es uno de los biblistas más conocidos y consultados actualmente en Italia. Tiene en su haber gran cantidad de ensayos, obras de divulgación y comentarios exegéticos de amplio calado. Se prodiga como conferenciante, colaborando también asiduamente en revistas, como Vida Nueva, y en periódicos como el diario Avvenire, L'Osservatore Romano o Il Sole 24 Ore. Son muy apreciadas sus frecuentes intervenciones en televisión, donde participa en diversos programas culturales. Su presencia en las redes sociales es igualmente sobresaliente, con numerosos seguidores. Todo esto le viene por su brillante dominio de la palabra escrita, siendo asimismo un placer escucharlo por su claridad expositiva, la riqueza y variedad de los autores que cita y sus grandes dotes de orador.

La obra que presentamos es breve en extensión y honda en su contenido. Digno de mención es el prólogo del volumen, redactado por el Subsecretario del Pontificio Consejo de la Cultura, Mons. Melchor Sánchez de Toca. Subrayo asimismo la belleza de la traducción del texto italiano al español, llevada a cabo con esmero por Pedro Ignacio Fraile Yécora, competente biblista. Ha sido igualmente un acierto que la presente edición contenga notas a pie de página, unas de carácter explicativo, para glosar cierta terminología usada por el autor, y otras indicadoras de la versión castellana de determinados libros citados por Ravasi en el cuerpo del texto.

En siete enjundiosos capítulos, el Purpurado, partiendo de la pregunta de Dios a Adán en el paraíso: “¿Dónde estás?" (Gén 3,9), formula sabias interpelaciones para esclarecer la hodierna situación existencial del ser humano. Leyendo estas páginas, percibimos que esa primordial interpelación divina no es una pregunta que pueda simplemente quedar atenazada en 